\title{
CREATING AN ATMOSPHERE: MEDIA AESTHETIC ANALYSIS OF JOURNALISTIC PROSPECTS
}

\author{
Marina V. ZAGIDULLINA \\ Chelyabinsk State University, Faculty of Journalism, \\ Journalism and Mass Communication Department, Br. Kashirinykh, 129, 454001, Chelyabinsk, Russia
}

Received 18 September 2019; accepted 16 January 2020

\begin{abstract}
In this article, journalistic practices are examined under the perspectives of 1) the theory of atmosphere in communication, 2) the creativity in journalism through the media aesthetic approach. This article contributes to both the theory of creativity in media industries, and the theory of aesthetic shift in current communication (with respect to the generation of atmospheric design in media). The empirical material used in this article was extracted from the Russian journalist Web portal Takie dela (English: So It Goes). The concept of "atmospheric creativity" in the current journalistic practices is developed.
\end{abstract}

Keywords: atmosphere in aesthetics, creativity in journalism, immersive journalism, media aesthetic analysis, multimodal journalism.

\section{Introduction}

Lev Vygotsky calls "tools" imagination and other forms of creative reflection (1986, p. 90, 107). Following his thoughts, one can say that imagination is the basis of the personal "creative faculty", and it can be developed like a multifold phenomenon. Lev Manovich, considering current communication, extends this metaphor. He emphasizes that interactions with information cannot be understood without a "multifold" approach combining at least two opposite aspects of human beings - "office" and "club" (Manovich, 2014, p. 42). Here, "office" is "pure cognitivism", and "club" can be described as a "purely embodied" (or "physical"). This conjunction of "office" and "club" is the only way to understand the "affectivity of data" (or the consumption of information, in general). This "embodiment" of cognitive (at first sight), rational activity leads us to understand the "aesthetic turn" in communication. Feelings, emotions, sensations of the communication process participants transform into an aesthetically organized performance. Thus, this "trend toward performance" of journalism projects can be considered as a part of this general process of aestheticization. In this article, we consider the analytic potential of the idea of "atmosphere" as a key to the explanation of

${ }^{*}$ Corresponding author. E-mail: mzagidullina@gmail.com 
actual journalism trends. This article is structured as follows: first, the theoretical part (the "atmosphere" concept in the context of current media industry); secondly, the principles of media aesthetic analyses; thirdly, media aesthetic analyses with an "atmospheric focus" are applied to an example of journalistic project (and "atmospheric creativity" in journalism is examined).

Literature review. Creativity has always been a target of a number of researches. One can find dozens of angles under which it can be studied. In this article, we only concentrate on creativity in journalism and media industry. Analyzing different approaches to creativity, Nando Malmelin and Lotta Nivari-Lindström combine them in three groups ("poetic", "metaphoric", "ambiguous"), and stress that the basic concept of creativity is related to the so called "standard definition of creativity" which has been developing since the 1950s (see 2017, p. 336; references to Barron, 1955; Stein, 1953). This definition states that creativity produces original, novel or unique ideas that are considered useful and appropriate (Runco \& Jaeger, 2012 , p. 92, 94). In their article, the researchers analyze the so called "implicit theories" of creativity developed by professionals of media industry, and they contribute to the theory of creativity by introducing the concept of "implementation" of existing ideas (rather than creating new ideas), proposing new ways of teamwork, and showing that commercial success is a consequence of creativity (Malmelin \& Nivari-Lindström, 2017, pp. 342, 344-346).

Another way of creativity conceptualization in media production is described by Mark Deuze (2019). His review does not refer to the same set of researches as in Malmelin's and Nivari-Lindström's article. This shows how broad of the field of creativity exploration is. Deuze searches for "three types" of creativity in journalism, and refers to Sarah Coffee's research ("romantic", "inspirational", "rational", see 2010, p. 3). For Deuze, the most important challenge in professional journalism is the rupture between the "intimacy shift" in media production (considered as a creative trend) and the "agentic power" of journalism (being closer to user's journalism leads to losing institutional and social "weight"; Deuze refers to Markham, 2012; also see Wilson, 1999; Steensen, 2016). Deuze concludes his review by redefining creativity in journalism: he states that it is related to social activism and commercial success inside the journalism field (like a "second-degree" journalism), where talented writers and creators have lasting conditions for their creativity (2019, pp. 131-132). It is important to note that Deuze comes to the same setting as Malmelin and Nivari-Lindström: creativity in the media industry always combines "inner forces" (such as talent), teamwork (the feeling of support) and "commercial success" (which can be considered as a frame, and an inspiration for talent) (2017, p. 344). When comparing "the standard definition" of creativity with these contributions we can see that in journalism (which is an important part of media industry) there has been a shift towards setting a creative process rather than obtaining a result. Commercial success can be considered as resulting from the "right implementation of talent": engaging the public, making a product which can "capture the attention" of users, get them involved in active consumption. That is why we can consider creativity in journalism in relation to the "atmosphere" of journalism projects.

"Atmosphere" as a key concept of contemporary aesthetic is theorized by Gernot Böhme $(1993,2003,2013)$. He opposes "the old aestheticism" with its logocentric, language-oriented "judgmental" character and "the new aestheticism" (which is body-oriented and related to 
sensations rather than thoughts, see Böhme, 1993, p. 114). Böhme refers to Walter Benjamin's "aura" (2010), and also to the German thinkers Ludwig Klages (see 1970, 1972) and Hermann Schmitz (see 1964). Expanding on the idea that atmosphere is a nature of aesthetic experience, Böhme details its structure (as a spatial phenomenon). The fact that the atmosphere is borderless, never verbalized, and exists only in the mood of the recipient, "narrows" the task of its exploration. Thus, in a special issue of the journal Visual Communication devoted to the production of atmosphere all articles were related to the spatial arts and their performances (Edensor \& Sumartojo, 2015).

We believe that the concept of atmosphere can be fruitfully applied to the field of journalism, even if journalistic projects are logocentric and non-spatial by nature. In general terms, journalism itself continuously shifts between "office" and "club" modes - as Manovich called them - between logos and image. This is how we understand atmosphere in the context of this article: the spatial characteristics of "screen-oriented" journalism production are similar to the set-up of, for example, a garden or a spectacle.

Method. Media-aesthetic analysis is used in this work to understand the nature of "atmospheric" journalist projects, to clarify the structure of a project and to explain its cultural significance. Manovich introduced the concept of media aesthetics to emphasize the importance of software in a computer-oriented period of culture $(2001,2014)$. He related "informational aesthetics" to "affective data". When the user handles "serious" data on his computer and at the same time listens to an MP3 player, he is involved in a complex media consumption where "office" and "club" cannot be dissociated. Media aesthetics appear as a combination of media content and media consumption. According to Bruno Latour, we can consider this consumption as a "network" (1993, pp. 3-7), where each agent has its role (the user's headset, his fingers, using the mouse and the keyboard, the ambient temperature, the personal computer quality the speed of internet access). This approach correlates with the idea of atmosphere as described by Böhme. Thus the media aesthetic analysis can be applied to "atmospheric-oriented" projects.

This analysis is based on the principles of multimodal discourse analysis (Leeuwen, 2005; O'Halloran, 2011; also see developing of this method: O'Halloran et al., 2018, 2019). But in the multimodal approach, the main goal is to include in the research visual images, sounds or other modes; these are considered as equal to the language semiotic systems. Multimodal researchers have analyzed discourses "grammatically", using a linguistic approach. Media aesthetics analysis is based on a dominant principle of research (which consist in describing the "tone" of the analyzed subject). In media aesthetic analysis, it is important to include a description of the process of consumption which is integrated in the project (i.e. how the user has to consume). As in any aesthetic approach, media aesthetic analysis cannot avoid a conflict between objectivity and subjectivity, nor a "judgmental" style of description.

The material of analysis. In this article, a media aesthetic analysis of an example of a journalist project is presented (Takie dela, 2017). The choice of this particular example is justified by prestigious international journalist awards obtained by this project (i.e. the creative festival Great Eight, World Press Photo 2018 etc.). These awards were related to both the project's content and format ("multimodal storytelling", "non-commercial digital project", "design"). This project is analyzed to determine the dominant factors of its multimodality which create the atmospheric effect work. Furthermore, specific information on the web portal Takie dela itself, and the project objectives is fundamental to complete the analysis. 
The web portal Takie dela was launched by the non-commercial fund Help Needed in 2015. Its goal is to apply high-standard journalism skills and efforts to the search of solutions for major social problems in Russia. The motto of this portal is We will put back the average person into the focus of contemporary media. Takie dela has now become one of the largest centers of charity and fundraising amongst Russian non-governmental organizations.

The special project "There once lived" contains five stories on Moscow, Russia region homeless people. Each story has its specific "tone" which we can analyze as "the atmosphere" of this story (Glebovich, 2019). Extending the idea of "atmosphere" to contemporary journalism, the combination of emotionally colored contents with visual technologies (adapted to screen-framing), and sounds (ambient noises which are "responsible" for the atmospheric effect) are analyzed in terms of media aesthetics.

\section{Discovering atmosphere as a media aesthetic effect}

O'Halloran et al. stress the importance of a precise analytical structuring of all multimodal entities (2010). They believe that only the "resemiotisation" of the elements which links all the units of communication will allow a full comprehension of the multimodal "texts" (these are currently considered as "extra-texts" because they include video, music, sounds and tools that can change the "nature" of this communication). O'Halloran describes how one can find the "setting of settings" (or "multiframing") which applies to a given moment of the communicative process. This "fragmentation" of a whole extra-text is probably the only way to analyze the latter; each fragment is examined individually, including the non-textual (nonverbal) elements, i.e. gazes, gestures, body postures, intonations, timbre of voice and so on).

But this analysis has its own limitation because no synthesis is provided after analysis: a puzzle of interesting but subjective conclusions on the semiotic keys of each frame or element is produced. At the same time, we fully agree with O'Halloran's approach to multimodal entities: each must be individually examined, "step by step", at each structural level, in their temporal continuity. However, this approach is not efficient for interactive journalistic projects where temporal continuity can greatly vary from user to user.

How can we extend multimodal discourse analysis to on-screen creative journalistic projects? By providing a media aesthetic analysis of the project dominant element. We can then describe the atmosphere of the journalistic project.

As an example, we will examine one of the five stories of the example project: "Esma" (Takie dela, 2017). Following our goal to describe the atmosphere of this project, we will move step by step along this project while discovering its atmospheric details. The front page of this story is organized as a combination of texts: the highlighted name of the heroine, her age (a "childish" font is used there), and a short teaser (Esma clashes with all who tried to help her). The "childish" font relates to the background picture: it is an imitation of a child drawing. Following O'Halloran's idea of "resemiotisation" of all elements which interact with each other, we can observe several contradictions: between the image of a city and autumn trees, "blind" buildings and buildings with "eye-windows", the "exotic" name of the heroine (split in two syllables, rendering it powerful) and her age (indicating weakness). The reader knows from the beginning that it will be a story about a homeless person. The front page 
organizes information about the central character in an emotionally-implicit manner: an old woman, alone in Moscow autumn streets (see Figure 1).

As Manovich noted, the media aesthetic approach is based on an embodied interaction between users and media, including a number of details which were missed out from traditional research considerations (2014, pp. 42-43). In Figure 1 one can see that during the process of downloading the content of this story (percentage of downloads is given in large characters) a recommendation appears: "Recommend watching with sound on and in fullscreen mode" (see Figure 2).

This recommendation, as we see, is complemented with two icons, which just duplicate this advice (a headset and a symbol of the fullscreen mode). From a multimodal analysis point of view, this is a signal marking the dominant semiotic resources of the project: sound and image. Furthermore, we cannot see the portrait of the heroine, it is replaced by her name

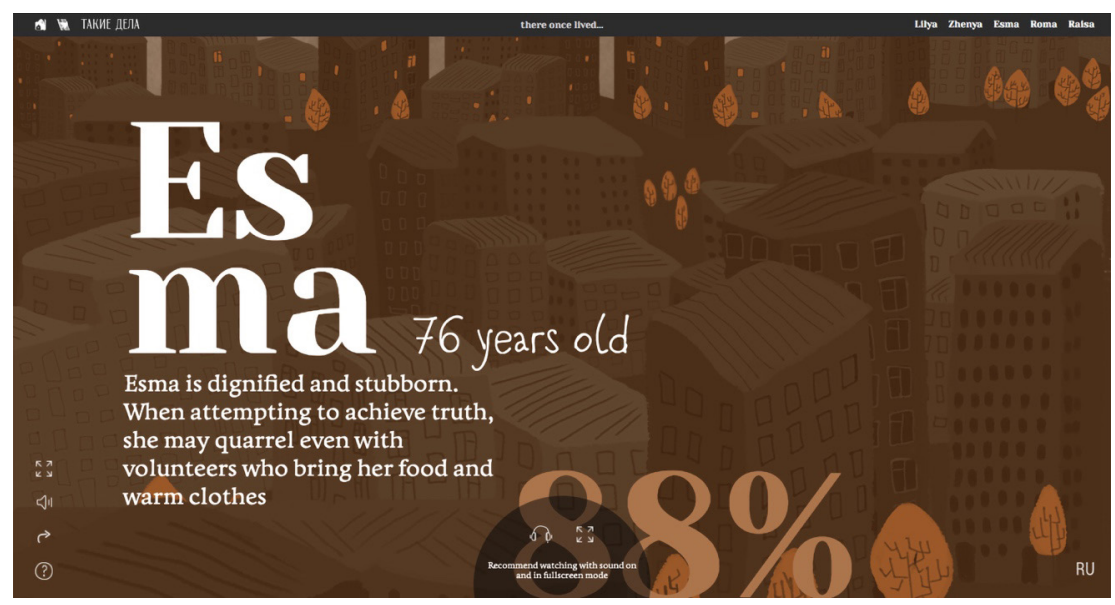

Figure 1. The front page of the story "Esma" (source: Takie dela, 2017)

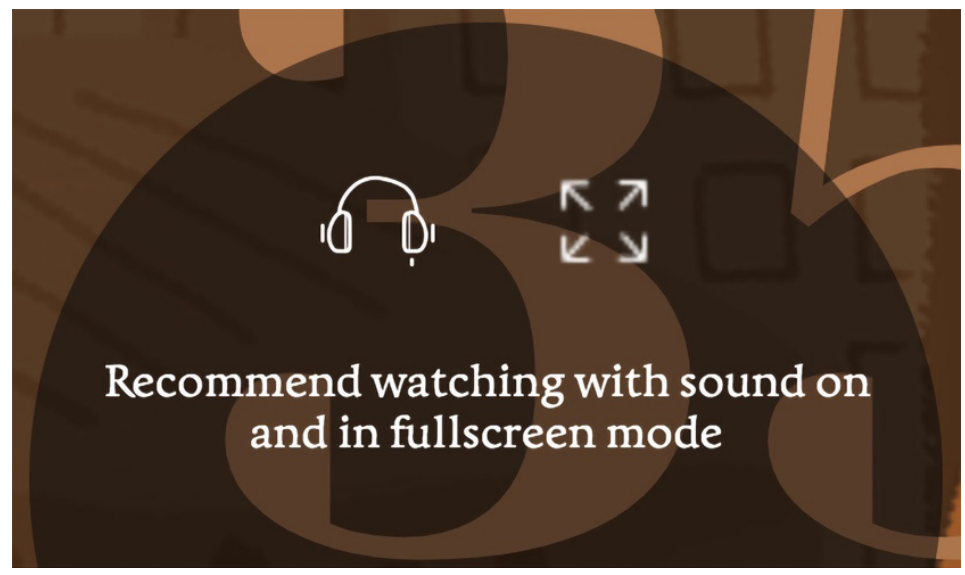

Figure 2. Recommendation to users on the front page of "Esma" (source: Takie dela, 2017) 
(four characters arranged in a square, as the frame of a portrait). One understands that the text (considered as one among many other possible semiotic resources, see Halliday, 1978) "works" not only as an information but also as an aesthetic tool (to be looked at rather than just read).

Latour believes that the instrumental part of communication (the user needs to put on his or her headset, to click on full-screen; also this recommendation makes it impossible or senseless to use a mobile version of the site; ideally "Esma" must be seen on big (wide) screen where what the user sees is "surrounded" by the story) is as important as the content, and the "linguistic turn" in communication is not relevant to the reality (1993, pp. 63-64). For Latour and his actor-network theory the icon with the headset is a sign of the active role of the device in this consumption of a journalistic project, and that is why even the quality of the user's headset is significant. The headset becomes an actor, and the fullscreen mode as well. This approach relates to the aesthetic of atmosphere (the user must close her/his ears with the headset and watch with a full screen. She/he is provided with an autonomous reality and fully immerses in the story).

The story of Esma can be read, listened to and watched only if the user interacts with the screen image. The scrolling "animates" the text and pictures, and ambient sounds function as an important part of the atmosphere of Esma's story representing the grey life of a homeless old woman in Moscow and her death at the hospital.

The first image of this story (when the front page is animated by the user) is the ambulance, which crosses the screen with the unpleasant sound of its siren. We can also hear ambient sounds of the big city, we can see how the the lights through building windows switch on and off. Here, the atmosphere of this story is organized as a prediction: the user is informed right at the start of the story that the heroine does not have a happy life nor will have a quiet death. The text "body" appears on a dark-grey background separately from the animated pictures. It has the same "childish" fonts as in the front page. The text is very simple and short (as if aimed for children). But this shortness is also a reference to the Bible (see Figure 3). The Biblical connotations of the text's ("There once lived a woman whose name

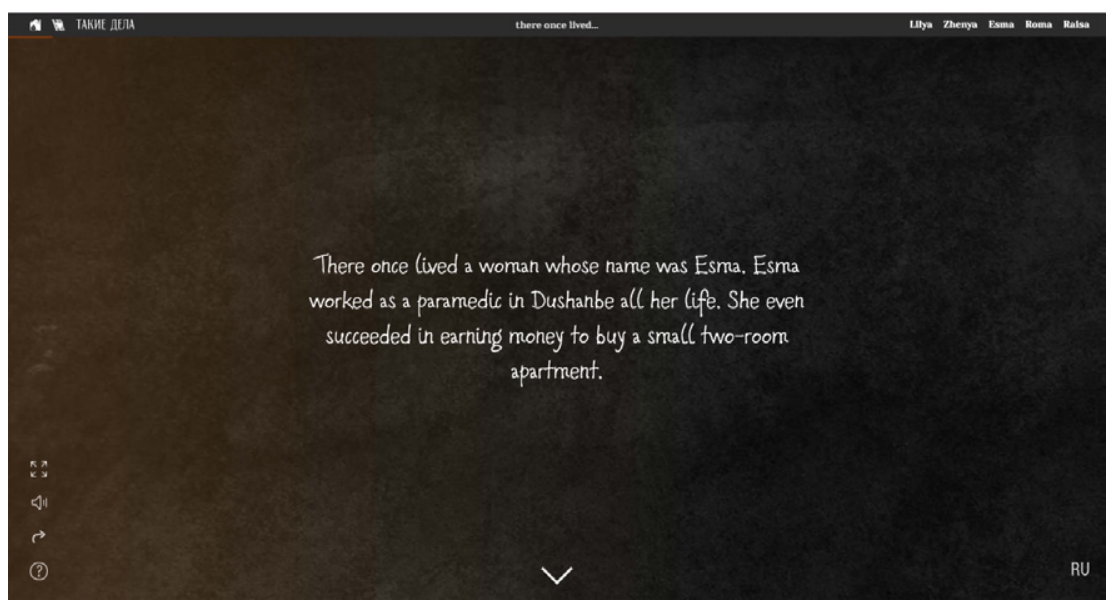

Figure 3. The design of the verbal part of "Esma" (source: Takie dela, 2017) 
was Esma" - "There was a man sent from God, whose name was John"; John 1:6) sacralizes this story. The color of the background with its gradient from red-brown on the left to dark grey or even black on the right makes this text (with its white characters) somber and even alarmful. But at the same time one can hear ordinary city noises, which create a contrast with this sacralized style. Following Gunther Kress and Theo van Leeuwen (2006), we can "read this image" - with a semiotic key - as the sign of a Biblical plot converted into a contemporary reality. But from the "atmospheric" angle the most important elements here are colors (darkness = sorrow) and sounds (ordinary and "non-human": we cannot hear voices, only noises and dogs barking).

Thus, users should be more involved in this "grief" (tragic) atmosphere than in a "sacred" remake of a Biblical text. We suppose that the recommendations in the preface of this story (use a headset and a "fullscreen mode") are strong markers of the dominant elements of multimodal journalistic projects, where atmospheric involvement is stronger than cultural references and background. This is how atmosphere can be detected in media projects: through the setting-up of the technical and technological conditions of consumption, and its implementation in the structure (or even the nature) of the project.

\section{What the "fullscreen mode" can provide}

In our example, attracting the users' attention to conditions such as a "full screen" can be considered as one of the dominant traits of this particular journalistic project. For media aesthetic analysis, it is a challenge to find an adequate interpretation to this new mode of expression. We can partly apply the principles of multimodal discourse analysis to this material in sequence. O'Halloran (2011, p. 130) demonstrates in her example how to analyze just several seconds of a television program (and it is a long and slow process considering the scrupulous description of each detail of this video, see Table 1). We suppose that this scrupulousness can work against the fruitfulness of this analysis (because the researcher can lose the dominant element of the multimodal entity; now O'Halloran and her colleagues use a specially developed multimodal analysis software, see O'Halloran et al., 2019). But the idea to follow sequentially the continuity of the media product (from the first element to the last one) is the only way to overcome subjective research interpretation.

In our analysis, we apply this "sequential" approach to one aspect of the example story the "fullscreen mode". The 2D animation in the design of "Esma" could never pretend to produce an effect of "virtual reality". It is rather a "schematic" description of places and events. But the "fullscreen mode" works like an atmosphere generator for this plot.

"Esma" is organized as a succession of "pictures" which mark the life of the heroine: she is a doctor - she is in her apartment in Dushanbe, Tajikistan - the crowd of Tajiks request the deportation of Russians in 1991 - Esma tries to find a place where she can live in Moscow - Esma at the bus station looks for food in a garbage container - she sleeps in a junk pile somewhere - Esma lays on a bed in the hospital and dies. How can "the fullscreen mode" create the atmosphere of this story? We can find several basic principles: 1) Esma is always shown as a "non-significant" part of the picture (she is disproportionately small comparing to her surroundings); 2) She is opposed to her environment in all the sequences of her life 
Table 1. The fragment of the multimodal discourse analysis (source: O'Halloran, 2011, p. 130)

\begin{tabular}{|c|c|c|c|c|c|c|c|c|c|c|}
\hline \multirow{3}{*}{$\begin{array}{l}\text { Slage } \\
\text { Phase } \\
\text { Sub-Phase } \\
\end{array}$} & \multirow{2}{*}{\multicolumn{10}{|c|}{$\begin{array}{c}\text { 'Petrol Prices' } \\
\text { Leaked Cabinet Documents }\end{array}$}} \\
\hline & & & & & & & & & & \\
\hline & \multicolumn{2}{|c|}{ Leaking Documents as Legal Issue } & \multicolumn{8}{|c|}{ Leaking Documents as Political Issue } \\
\hline & & & SHOis & & & & & & SHOT 4 & SHOT 5 \\
\hline \\
\hline & Frame 1 & Frame 2 & Frame 2 & Frame 4 & Frame 5 & Frame 6 & Frame 7 & Frame 8 & Frame 9 & Frame 10 \\
\hline \multicolumn{11}{|l|}{$\begin{array}{l}\text { SEMIOTIC } \\
\text { RESOURCE: }\end{array}$} \\
\hline \multicolumn{11}{|l|}{ Speech: } \\
\hline $\begin{array}{l}\text { Speaker 1- } \\
\text { Tony Jones } \\
\text { (interviewer): }\end{array}$ & $\begin{array}{c}\text { Alright } \\
\text { Tony Abbort }\end{array}$ & $\begin{array}{l}\text { you we been in the } \\
\text { rrenches. That's } \\
\text { fair enough isn't } \\
\text { it? }\end{array}$ & & & 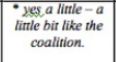 & \begin{tabular}{|c|}
$\begin{array}{c}\text { Leaking going on } \\
\text { all round }\end{array}$ \\
\end{tabular} & & & & \\
\hline $\begin{array}{l}\text { Speaker 2- } \\
\text { Tony Abbott: }\end{array}$ & & Ah, yes it is & $\begin{array}{l}\text { but the interesting } \\
\text { thing is that the } \\
\text { new government } \\
\text { is already }\end{array}$ & \begin{tabular}{|c|} 
leaking, Tony. \\
I mean normally \\
it takes many \\
years
\end{tabular} & $\begin{array}{c}\text {-before a - before } \\
- \text { before a } \\
\text { government }\end{array}$ & $\begin{array}{l}\text { W. WellII- } \\
\text { Tired old } \\
\text { governments }\end{array}$ & $\begin{array}{c}\text { leak } \\
\text { New, smart, } \\
\text { clever. }\end{array}$ & $\begin{array}{c}\text { intelligent } \\
\text { governments } \\
\text { aren 's supposed } \\
\text { to }\end{array}$ & $\begin{array}{c}\text { leak and the fact } \\
\text { that this } \\
\text { government is } \\
\text { leaking so badly }\end{array}$ & $\begin{array}{l}\text { so early is a } \\
\text { pretty worrying } \\
\text { sign. }\end{array}$ \\
\hline \multicolumn{11}{|l|}{\begin{tabular}{|l|} 
Kinetic Features: \\
\end{tabular}} \\
\hline Gaze: & $\begin{array}{l}\text { 9ff-screen; } \\
\text { engaged; directed } \\
\text { at interviewer }\end{array}$ & $\begin{array}{c}\text { off-screen; } \\
\text { engaged; directed } \\
\text { at Tony Abbott }\end{array}$ & $\begin{array}{l}\text { offi-screen; } \\
\text { disengaged; } \\
\text { directed at self }\end{array}$ & \begin{tabular}{|c|} 
off-screen; \\
engaged; directed \\
at studio \\
audience//inter- \\
viewer/Tanya \\
Plibersek
\end{tabular} & \begin{tabular}{|c|} 
off-screen; \\
engaged; directed \\
at studio \\
audience//inter- \\
viewer/Tanya \\
Plibersek
\end{tabular} & $\begin{array}{c}\text { Qffi-screen; } \\
\text { engaged; directed } \\
\text { at cameraviewer }\end{array}$ & \begin{tabular}{|c|} 
Qfip-screen; \\
engaged; directed \\
at studio \\
audience//inter- \\
viewer/Tanya \\
Plibersek
\end{tabular} & \begin{tabular}{|c|} 
off-screen; \\
engaged; directed \\
at studio \\
audience//inter- \\
viewer/Tanya \\
Plibersek
\end{tabular} & \begin{tabular}{|c|} 
off-screen; \\
engaged; directed \\
at Tony Abbott
\end{tabular} & $\begin{array}{c}\text { off-screen; } \\
\text { engaged; directed } \\
\text { at studio } \\
\text { audience//inter- } \\
\text { viewer/Tanya } \\
\text { Plibersek }\end{array}$ \\
\hline Body Posture: & angled. & $\begin{array}{l}\text { angled; leans } \\
\text { forward toward } \\
\text { Tony Abbott } \\
\end{array}$ & angled; leans back & angled & angled & straight & angled & angled & angled. & angled \\
\hline Gesture: & & & $\begin{array}{l}\text { raises, hand; } \\
\text { palm facing } \\
\text { outward }\end{array}$ & $\begin{array}{l}\text { raises hand; } \\
\text { palm facing } \\
\text { outward }\end{array}$ & $\begin{array}{l}\text { hand raised; } \\
\text { palm facing } \\
\text { outward }\end{array}$ & $\begin{array}{l}\text { both hands raised; } \\
\text { palms facing } \\
\text { outward/cach } \\
\text { other }\end{array}$ & $\begin{array}{c}\text { both hands raised; } \\
\text { palms facing } \\
\text { outward/each } \\
\text { other; gap } \\
\text { narrowing }\end{array}$ & $\begin{array}{c}\text { both hands raised, } \\
\text { palms facing } \\
\text { outward/each } \\
\text { other, gap } \\
\text { narrowing }\end{array}$ & & $\begin{array}{l}\text { both hands raised; } \\
\text { palms facing } \\
\text { outward cach } \\
\text { other at reduced } \\
\text { distance, } \\
\text { downward } \\
\text { movement }\end{array}$ \\
\hline \multicolumn{11}{|l|}{ Cinematography: } \\
\hline $\begin{array}{l}\text { Camera Angle } \\
\text { (horizontal } \\
\text { perspective) }\end{array}$ & $\begin{array}{l}\text { obliquel } \\
\text { detached }\end{array}$ & $\begin{array}{l}\text { oblique/ } \\
\text { detached }\end{array}$ & $\begin{array}{l}\text { obliquel } \\
\text { detached }\end{array}$ & $\begin{array}{l}\text { obliquel } \\
\text { detached }\end{array}$ & $\begin{array}{l}\text { oblique! } \\
\text { detached }\end{array}$ & $\begin{array}{l}\text { frontal } \\
\text { involved }\end{array}$ & $\begin{array}{l}\text { obliguef } \\
\text { detached }\end{array}$ & $\begin{array}{l}\text { oblique' } \\
\text { detached }\end{array}$ & $\begin{array}{l}\text { sbliquel } \\
\text { detached }\end{array}$ & $\begin{array}{l}\text { obliquel } \\
\text { detached }\end{array}$ \\
\hline Size of Frame & $\begin{array}{l}\text { medium } \\
\text { close-up }\end{array}$ & $\begin{array}{l}\text { medium } \\
\text { close-up }\end{array}$ & $\begin{array}{l}\text { medium } \\
\text { close-up }\end{array}$ & $\begin{array}{l}\text { medium } \\
\text { close-up }\end{array}$ & $\begin{array}{l}\text { medium } \\
\text { close-up }\end{array}$ & $\begin{array}{l}\text { medium } \\
\text { close-up }\end{array}$ & $\begin{array}{l}\text { medium } \\
\text { closs-up }\end{array}$ & $\begin{array}{l}\text { medium } \\
\text { closs-up }\end{array}$ & $\begin{array}{l}\text { medium } \\
\text { close-up }\end{array}$ & $\begin{array}{l}\text { medium } \\
\text { close-up }\end{array}$ \\
\hline
\end{tabular}

(she is lonely in her empty apartment which does not look like a cozy place, the big crowd has threatening gestures and slogans, she is lost in the labyrinth of doors where she tries to find a place for living or with the big buses all around her, she is miserable in her bed in a corner of the hospital room). Esma is never in the center of the screen (we can only realize this when using the wide screen mode), and that is why fullscreen generates an atmosphere of loneliness and "tosca" (the Russian word for eternal grief).

\section{Sounds as an extra-text}

The most important tool of atmospheric effect is the sound arrangement. Ambient sounds can also be analyzed as sequential (in their continuity), and the appearance of music marks the closure of the story as well as the "peak" of its emotional status: sounds of ambulances and other cars - a baby cries in the big building where Esma's apartment is located - loud and threatening voices of the Tadjik crowd, sound of fire where they are probably burning Soviet symbols - unpleasant voices and sounds of opening and closing doors - car sounds Esma's heavy and unhealthy breathing - music and vocal (minor). The analysis of the sound arrangement show several key characteristics: 1) there are no words (even when the crowd cries, one can only hear unintelligible phrases, and the vocal in the music is also without words); 2) the sounds often come from to the unseen part of the environment (dogs, babies, a choir) extending the visible world and making it even wider than the fullscreen mode can provide; 3 ) music accompanies the transformation of the heroine: she is on a cold junk pile sleeping on three chairs, she is on a bed in the hospital, her body is on the same bed prepared for the funeral, the same bed is empty. The "liturgy-like" music in "Esma" returns users to 
the Biblical context of this story: the end of the heroine's life is represented by the dormition of the Mother of God icon (see Figures 4, 5).

The big white platok (Esma's head-shawl) alludes to the halo of the Mother of God. In the same scene, one can see other patients of the hospital: they are knitting, reading, continuing their own life and are completely indifferent to the death of this homeless woman. Even when she is surrounded by charity helpers as she is dying in the hospital (and not in the street), she

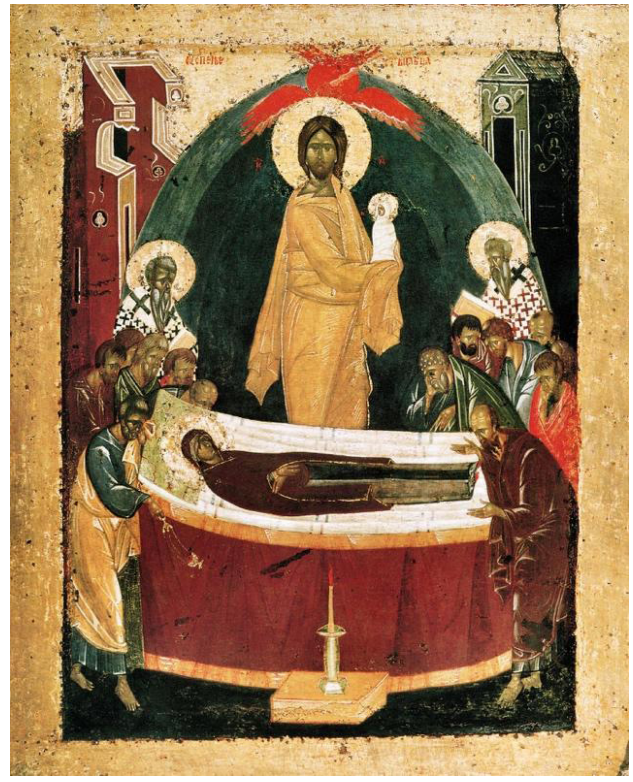

Figure 4. El Greco. Dormition of the Mother of God (Russian: Uspenie Bogoroditsy, 1392). The other side of an icon Our Lady of the Don (Russian: Donskaya Bogomater') (source: Wikipedia: The Free Encyclopedia, 2019)

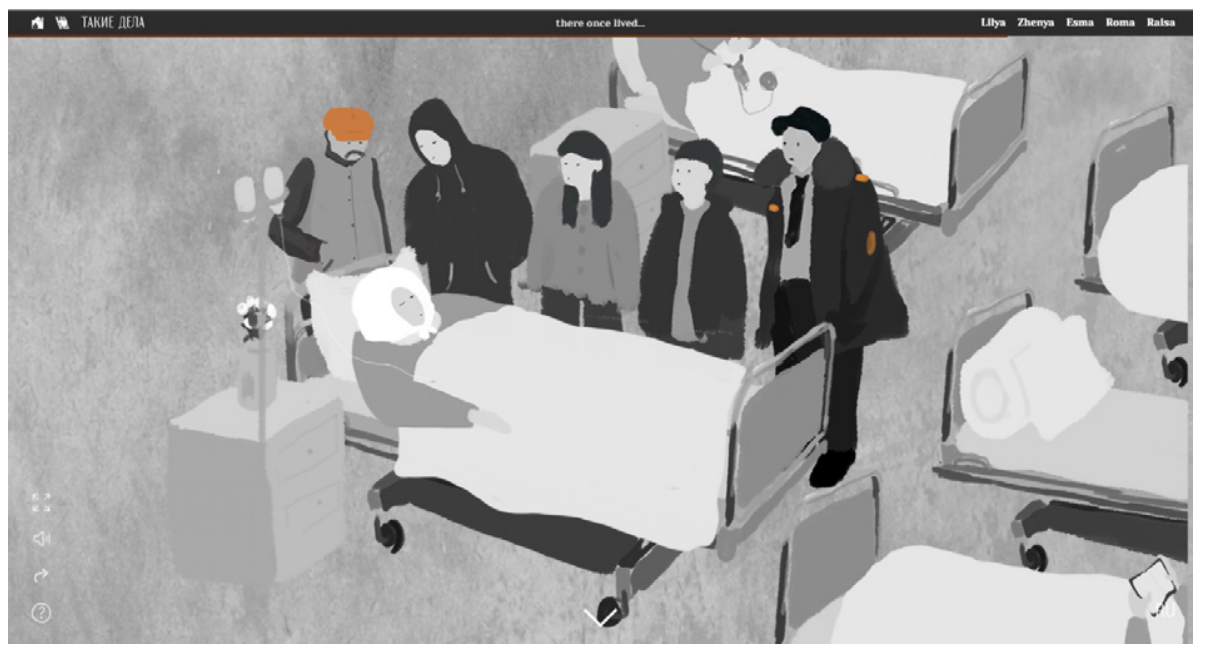

Figure 5. A fragment of "Esma" (the death of the heroine) (source: Takie dela, 2017) 
is alone and unhappy (this refers to the very first phrase of this story: "[...] she may quarrel even with volunteers who bring her food and warm clothes") (Takie dela, 2017).

The conjunction of the aesthetic effect of sounds and the "fullscreen mode" helps describe the atmosphere of this journalistic project: it aims to create a cathartic reaction of the user. Even if we discover the cultural references of the sacred plots and images we have to stay in this atmosphere of tragedy, of emptiness of life, of loss of sense and taste (this is in complete opposition with the sacred atmosphere of the orthodox liturgy).

\section{Conclusions: atmosphere is active}

In this article, the method of dominant media-aesthetic analysis was explored. This approach can make the multimodal discourse analysis less complicated and more fruitful. Our findings are the following:

- The search for the dominant element in any media phenomenon should be based on the analysis of the significant technologies and techniques which were used in the creation of this object.

- The analysis of the dominant element can be organized around the allusions and emotional persuasiveness of the journalistic project.

- An atmosphere can contradict cultural references and overcome them.

- Creating of an atmosphere in a journalistic project is the process of involving the user in co-participation: her/his cathartic reaction can lead to expected actions offline (e.g. a donation).

We need to provide some explanations to the last point: at the end of "Esma" the authors of this projects invite users to donate for charity purposes. This approach in journalism (monetization of the content) can be considered as an answer to the biggest challenge of the digital era in professional journalism (conventionally free circulation of information in the web-space). Here, the user does not pay the journalist but contributes to the struggle for a better life for everyone. This empathic principle needs to be checked (how is the management of donations organized by this particular site?) but the "visible" mechanism of Takie dela is a motivator for users: creating an atmosphere triggers the users' wish to help.

The limitations of this approach can be listed as follows:

- Subjectivity in the search for the dominant element (no strict procedure was provided; we believe that here, the role of the researcher's intuition is most important).

- The "holism" of any multimodal project (all tools work simultaneously and this makes the search for the dominant element difficult).

- The cultural gap between generations (the explanation of cultural precedents and references can be completely wrong from the researcher's point of view).

Nonetheless, the media aesthetic analysis, based on a multimodal discourse analysis, shows its significance for the current communication field where textual-centered information exchange is increasingly complemented by different semiotic resources.

\section{Funding}

This work was supported by the Russian Science Foundation under Grant 18-18-00007. 


\section{References}

Barron, F. (1955). The disposition toward originality. The Journal of Abnormal and Social Psychology, 51(3), 478-485. https://doi.org/10.1037/h0048073

Benjamin, W. (2010). The work of art in the age of mechanical reproduction. London: Prism Key Press.

Böhme, G. (1993). Atmosphere as the fundamental concept of a new aesthetics. Thesis Eleven, 36(1), 113-126. https://doi.org/10.1177/072551369303600107

Böhme, G. (2013). The art of the stage set as a paradigm for an aesthetics of atmospheres. Ambiances: Environnement sensible, architecture et espace urbain. https://pdfs.semanticscholar.org/345f/ e99a788bb60c042cb541c52b2c93dbe49875.pdf?_ga=2.198816175.1237635802.1574435684199233841.1528889777

Böhme, G. (2003). The space of bodily presence and space as a medium of representation. In M. Hård, A. Lösch, \& D. Verdicchio (Eds.), Transforming spaces: the topological turn in technological studies (pp. 1-7). Darmstadt: University of Technology Darmstadt. https://pdfs.semanticscholar.org/f5a2/ c65023e437eeb398222f601b052ec42875ed.pdf

Coffee, S. (2010). Exploring creativity through freelance journalism: testing out the systems model. https://pdfs.semanticscholar.org/c63f/c500b78b97b1a1d7963b375dfdf984f41d38.pdf?_ ga $=2.110913996 .854713691 .1579118179-199233841.1528889777$

Deuze, M. (2019). On creativity. Journalism, 20(1), 130-134. https://doi.org/10.1177/1464884918807066

Edensor, T., \& Sumartojo, Sh. (2015). Designing atmospheres: introduction to special issue. Visual Communication, 14(3), 251-265. https://doi.org/10.1177/1470357215582305

Halliday, M. A. K. (1978). Language as social semiotic: the social interpretation of language and meaning. London: Edward Arnold.

Glebovich, T. A. (2019). Sostradaniye kak kul'turnyy perekrestok: o nekotorykh osobennostyakh istoriy bezdomnykh na portale Takiye dela. In O. Avtokhutdinova, B. Lozovskij, I. Zinov'ev, V. Oleshko, E. Chepkina, Y. Chemyakin, \& E. Golousova (Eds.), Tsifrovizatsiya kommunikativno-kul'turnoy pamyati: rol' zhurnalistiki kak sotsial'nogo instituta (pp. 24-28). Yekaterinburg: Ural Federal University Publications.

Klages, L. (1970). Grundlegung der Wissenschaft vom Ausdruck. Bonn: Bouvier.

Klages, L. (1972). Vom kosmogonischen Eros. Bonn: Bouvier.

Kress, G., \& Leeuwen, van Th. (2006). Reading images: the grammar of visual design. London and New York: Routledge. https://doi.org/10.4324/9780203619728

Latour, B. (1993). We have never been modern. Cambridge, MA: Harvard University Press.

Leeuwen, van Th. (2005). Introducing social semiotics. London: Routledge. https://doi.org/10.4324/9780203647028

Malmelin, N., \& Nivari-Lindström, L. (2017). Rethinking creativity in journalism: implicit theories of creativity in the Finnish Magazine industry. Journalism, 18(3), 334-349.

https://doi.org/10.1177/1464884915620272

Manovich, L. (2014). Post-media aesthetics. In M. Kinder \& T. McPherson (Eds.), Transmedia frictions: the digital, the arts, and the humanities (pp. 34-44). Oakland, CA: University of California Press. https://doi.org/10.1525/9780520957695-006

Manovich, L. (2001). The language of new media. Series: Leonardo. R. F. Malina (Series Ed.). Cambridge: The MIT Press.

Markham, T. (2012). The politics of journalistic creativity: expressiveness, authenticity and de-authorization. Journalism Practice, 6(2), 187-200. https://doi.org/10.1080/17512786.2011.616651

O'Halloran, K. L. (2011). Multimodal discourse analysis. In K. Hyland \& B. Paltridge (Eds.), The Bloomsbury companion to discourse analysis (pp. 120-137). London, New York: Continuum. 
O'Halloran, K. L., Tan, S., Pham, D.-S., Bateman, J., \& Vande Moere, A. (2018). A digital mixed methods research design: integrating multimodal analysis with data mining and information visualization for big data analytics. Journal of Mixed Methods Research, 12(1), 11-30. https://doi.org/10.1177/1558689816651015

O'Halloran, K., Tan, S., Smith, B., \& Podlasov, A. (2010). Challenges in designing digital interfaces for the study of multimodal phenomena. Information Design Journal, 18(1), 2-21. https://doi.org/10.1075/idj.18.1.02hal

O'Halloran, K., Wignell, P., \& Tan, S. (2019). Doing critical discourse studies with multimodality: from metafunctions to materiality by Per Ledin and David Machin. Critical Discourse Studies, 16(5), 514-521. https://doi.org/10.1080/17405904.2018.1556173

Runco, M. A., \& Jaeger, G. J. (2012). The standard definition of creativity. Creativity Research Journal, 24(1), 92-96. https://doi.org/10.1080/10400419.2012.650092

Schmitz, H. (1964). System der Philosophie. Vol. 3. Bonn: Bouvier.

Steensen, S. (2016). The intimization of journalism. In T. Witschge, C. W. Anderson, D. Domingo, \& A. Hermida (Eds.) (pp. 113-127), The SAGE handbook of digital journalism. Los Angeles: SAGE. https://doi.org/10.4135/9781473957909.n8

Stein, M. I. (1953). Creativity and culture. The Journal of Psychology, 36(2), 311-322. https://doi.org/10.1080/00223980.1953.9712897

Takie dela. (2017). There Once Lived.... Esma, 76 Years Old. https://takiedela.ru/homeless/en/story3/

Vygotsky, L. (1986). Thought and language. Kozulin, A. (Ed.). Cambridge, MA: The Massachusetts Institute of Technology.

Wikipedia: The Free Encyclopedia. 2019. Dormition of the mother of god. https://en.wikipedia.org/wiki/ Dormition_of_the_Mother_of_God\#/media/File:Theofanus_uspenie.jpg

Wilson, E. (1999). The bohemianization of mass culture. International Journal of Cultural Studies, 2(1), 11-32. https://doi.org/10.1177/136787799900200102

\title{
TERPĖS KÜRIMAS: ŽURNALISTIKOS PERSPEKTYVŲ ESTETINE MEDIJŲ ANALIZE்
}

\author{
Marina V. ZAGIDULLINA
}

\section{Santrauka}

Šiame straipsnyje žurnalistikos praktika tyrinejama, remiantis komunikacijos terpès teorija ir kūrybiškumu žurnalistikoje estetiniu medijų požiūriu. Šiuo straipsniu prisidedama tiek prie kūrybiškumo teorijos medijų industrijose, tiek prie estetinio pokyčio teorijos dabartineje komunikacijoje (atsižvelgiant ị modeliuojamos terpès kūrimą medijose). Šiame straipsnyje naudota Rusijos žurnalistų interneto svetainès Takie dela (liet. Tokie reikalai) empirinè medžiaga. Dabartinèje žurnalistikos praktikoje plètojama „terpès kūrybiškumo“ koncepcija.

Reikšminiai žodžiai: terpè estetikoje, kūrybiškumas žurnalistikoje, įtraukioji žurnalistika, estetinè medijų analizè, daugiakryptė žurnalistika. 